\title{
Influence of lettuce as cover crop of the soil on sprinkler irrigation uni- formity and parameters of efficiency
}

\author{
Patricia Angélica A Marquesi'; Mário Alberto L Fonseca ${ }^{2}$; Pedro V Baldotto ${ }^{1}$ \\ ${ }^{1}$ UNOESTE-CCA, Rod. Raposo Tavares, km 572, 19067-175 Presidente Prudente-SP; ${ }^{2}$ Agrícola Taez, R. Osvaldo Cruz 952, $17930-000$ \\ Tupi Paulista-SP; pmarques@unoeste.br, agromfonseca@yahoo.com.br, baldotto@unoeste.br.
}

\begin{abstract}
The effect of lettuce as cover crop was evaluated on sprinkler irrigation uniformity and parameters of efficiency. The experiment was carried out in field at the Universidade do Oeste Paulista, in Presidente Prudente, São Paulo, Brazil, from August to October, 2006. One treatment was performed on bare soil and the other using lettuce cultivar Vera as cover crop, at the end of the cycle. The average water depth, application rate, uniformity of distribution coefficient, Christiansen uniformity coefficient, Hawaiian uniformity coefficient, as well as the statistical uniformity coefficient were evaluated. The following plant spacing were simulated: $12 \times 12,12 \times 18$, and $18 \times$ $18 \mathrm{~m}$. The highest water depth retained with lettuce crop cover, at the end of the cycle was $2.4 \mathrm{~mm}$, applied when sprinklers were spaced at $12 \times 12 \mathrm{~m}$. The same occurred in the application rate with an average reduction of $43 \%$. When the overlapping was performed, the crop cover did not influence the parameters of efficiency and uniformity, assuring the distribution of the irrigation depth. Neither treatment reached the expected rate concerning the water depth average or the application rate in the spaces. The treatment using cover crop presented the lowest value, with a water depth average below the intended amount. Therefore, the lettuce as cover crop promotes the reduction of applied water depth. Consequently, the irrigation time has to be increased to assure the expected water depth.
\end{abstract}

Keywords: Lactuca sativa L., irrigation assessment, irrigation management.

\section{RESUMO}

Influência da cobertura vegetal com alface sobre os parâmetros de eficiência e uniformidade da aspersão

O efeito da cobertura vegetal promovido pela alface foi avaliado nos parâmetros de eficiência e uniformidade da irrigação por aspersão. O experimento foi instalado em campo da Universidade do Oeste Paulista, em Presidente Prudente-SP, de agosto a outubro de 2006, sendo um tratamento com solo nu, sem cobertura vegetal, e outro tratamento com solo com cobertura vegetal (alface cultivar Vera no final do ciclo). Foram avaliados a lâmina média aplicada, intensidade de aplicação, coeficiente de uniformidade de distribuição, coeficiente de uniformidade de Christiansen, coeficiente de uniformidade havaiano e coeficiente de uniformidade estatístico. Foram simulados os espaçamentos de 12 x 12, 12 x 18 e 18 x 18 m. A maior lâmina retida pela cobertura vegetal com alface ao final do ciclo foi de $2,4 \mathrm{~mm}$ da lâmina aplicada, quando os aspersores estavam no espaçamento 12 x $12 \mathrm{~m}$. O mesmo espaçamento promoveu uma redução média de $43 \%$ na intensidade de aplicação. Quando realizadas as sobreposições, a cobertura vegetal não promoveu diferenças nos parâmetros de eficiência e uniformidade, garantindo a distribuição da lâmina de irrigação. Para a lâmina média e a intensidade de aplicação nos espaçamentos, nenhum dos tratamentos alcançou o valor esperado, sendo que o tratamento com cobertura vegetal apresentou o menor valor, com uma lâmina aplicada abaixo da pretendida. Portanto, a cobertura vegetal com alface promove redução na lâmina aplicada, sendo necessário aumentar o tempo de irrigação para garantir a lâmina desejada.

Palavras-chave: Lactuca sativa L., avaliação da irrigação, manejo da irrigação.

(Recebido para publicação em 11 de dezembro de 2008; aceito em 25 de agosto de 2009)

(Received in December 11, 2008; accepted in August 25, 2009)

$\mathrm{L}$ ettuce (Lactuca sativa L.) is Jone of the most consumed fresh vegetables in Brazil. Owing to its easily perishable condition and low resistance to transport, it is cultivated near the large consumer centers called "green belts" (Silva et al., 2000). In Brazil the major production of lettuce is concentrated in São Paulo State, where summer and winter cultivars are planted round the year using an irrigation system (Andrade
Júnior et al., 1992). The cultivar Vera is widely used with harvests performed between 50 and 70 days after the sowing (Trani et al., 2005).

In modern agriculture, irrigation equipment has become outstanding due to the latest technological developments both at the industries which have been their producers as well as in terms of the agronomic knowledge regarding the correlation water-soil-plant. Concerning the sprinkler irrigation, the system must be evaluated after the project implantation in order to determine whether its performance attends to the pre established planning, analyze the possible demanded adjustments to improve its performance as well as assess the quality of maintenance and the managing of the system.

In order to obtain an efficient irrigation it is necessary to use the 
correct amount of water, as pre set by the project, in a uniform application on the area. According to Silva et al. (2006), it is essential to analyze the spatial distribution of the water applied on irrigated areas to implement the most adequate strategies for the irrigation managing.

Once the sprinklers apply water in a circular form, overlapping must be used to obtain satisfactory uniformity (Frizzone \& Botrel, 1996; Pereira, 2003). In the conventional sprinkler system the most used plant spaces are $12 \times 12,12 \times 18,12 \times 24,18 \times 18,18$ $\mathrm{x} 24,18 \times 30,24 \times 24,24 \times 30,30$ $\mathrm{x} 30$, chosen according to each kind of sprinkler. (Bernardo et al., 2005). According to Mateos (2006), the use of sprinkler irrigation performance parameters by using a grading sampling and scenario simulation represents a good performance estimate in total area.

It is common to express the water distribution uniformity in an irrigation system by a uniformity of distribution coefficient which shows the variability of the water depth applied on the soil (Brennan, 2008). The lack of uniformity in the water application makes some parts of the irrigated area become soaked whereas others remain under irrigated (Silva, 2006; Brennan, 2007). The efficiency measures quantify the quality of the irrigation physically and depend on the uniformity of the water application and the managing of the system. Several authors have used these measures to assess the water distribution in the sprinkler irrigation systems. (Rezende et al., 1998; Rodrigues et al., 2001; Paz et al., 2002; Freitas et al., 2003; Drumond et al., 2006; Silva, 2006; Kara et al., 2008).

Christiansen (1942) was the first to propose a coefficient to establish the water distribution uniformity in irrigation systems. The author used the mean absolute deviation to express the water depth dispersion. According to Frizzone (1992) the CUC (Christiansen uniformity coefficient) has been the simplest and mostly used. It expresses the variability of the water depths on the soil surface and is mainly influenced by the sprinklers spacing, wind speed and operating pressure.

Hart (1961) proposes a uniformity coefficient (Hawaiian Uniformity Coefficient (HUC)) which also incorporates the standard deviation. The Sugar Cane Association of Hawaii (HSPA) sponsored the development of such coefficient. Wilcox \& Swailes (1947) proposed another coefficient denominated statistical uniformity (SUC), which uses the standard deviation as dispersion means.

According to Frizzone \& Botrel (1996) and Rezende et al. (1998) ABNT recommends the analyses of water distribution through the uniformity in the portion of the irrigated area with less water. Thus, the UDC (The Uniformity of Distribution Coefficient) is used to relate the fourth part of the total irrigated area with less water to the average water depth. A UDC is frequently used to indicate the problems in the irrigation water distribution. A low value can indicate excessive loss of water due to deep percolation in case the applied water depth corresponds to the intended water depth. High uniformity rates are related to smaller spaces between sprinklers. Paz et al. (2002) recommended a UDC average value of $80 \%$ for sprinkler irrigation. Frizzone \& Botrel (1996) and Zocoller (1999) recommended the average values of $82 \%$ to $88 \%$ for CUC and $70 \%$ to $80 \%$ for UDC, as adequate for cultures whose radicular system explores the first 0,40 $\mathrm{m}$ of the soil, basically.

The objective of this experiment was to evaluate the effect of lettuce as cover crop by the foliar interception of the irrigation water depths on the efficiency and the sprinkler irrigation uniformity at the moment of irrigation through the parameters of the average water depth, the application rate, uniformity of distribution coefficient, Christiansen and Hawaiian uniformity coefficients and statistical uniformity coefficient.

\section{MATERIAL AND METHODS}

The research was installed in the experimental area of UNOESTE in Presidente Prudente, São Paulo State

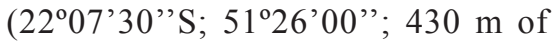

altitude), from August to October, 2006. A sprinkler system was installed with Agropolo NY-30 sprinkler, nozzles of $6.20 \times 4.60 \mathrm{~mm}$, operating pressure of $245 \mathrm{kPa}$ at the bottom of the ascension pipeline, flow rate of $2430 \mathrm{~L} \mathrm{~h}^{-1}$ and jet inclination angle of $30^{\circ}$ and ascension pipeline of $1 \mathrm{~m}$, values defined in the project. The lateral and main pipelines of PVC, were installed with quick couplers, spaces of $12 \mathrm{~m}$, flow rate of $60 \mathrm{mca}(\mathrm{PN} 60 ; 588 \mathrm{kPa})$ and diameter of $50 \mathrm{~mm}$. Two treatments with 10 replications were tested in the field, in the same area, in two distinctive periods; 1) bare soil without cover crop before the transplantation and 2) soil with lettuce (cultivar Vera) as cover crop, at the end of the cycle, 50 days after the transplantation, directly in the seedbeds spaced $30 \times 30 \mathrm{~cm}$ reaching the maximum foliar area.

The test consisted of the installation of 80 pluviometers with $10 \mathrm{~cm}$ of diameter $\left(78.54 \mathrm{~cm}^{2}\right)$ displayed in a net arrangement, $1.5 \mathrm{~m} \times 1.5 \mathrm{~m}$ around the individual sprinkler, being the first collectors of the first row and column placed on half the space $(75$ $\mathrm{cm})$. Frizzone \& Dourado Neto (2003) recommend the use of the collectors with a minimum area of $50 \mathrm{~cm}^{2}$ leading to a minimum of $8 \mathrm{~cm}$ of diameter. The collectors were installed under the culture dossel at $2 \mathrm{~cm}$ over the soil to enable catching the non intercepted irrigation depth by the foliar area of the culture. The volumes were obtained directly from the collectors at the end of the test using a glass test tube of 25 $\mathrm{mL}$ graded in $0.5 \mathrm{~mL}$. This group of collectors represented the upper left side square within the sprinkled area. The values were established according to the methodology of Frizzone (1992) and the American Society of Agricultural Engineering (1989) joining 289 collectors. The test lasted 15 minutes. The speed and wind direction were registered for each experiment (Table 1).

To evaluate the influence of the sprinkler irrigation depth performed by the foliar interception of the culture, we determined: water depth average applied (Equation 1); application rate (Equation 2); uniformity of distribution 
Table 1. Date and wind characterization for each replication (test) conducted between 9:00 am to 9:15 am (data e caracterização do vento para cada repetição (ensaio) realizado no período das 9:00 às 9:15 horas). Presidente Prudente, UNOESTE, 2006.

\begin{tabular}{lcccc}
\hline Treatments & $\begin{array}{c}\text { Repli- } \\
\text { cation }\end{array}$ & Date & $\begin{array}{c}\text { Speed of the } \\
\text { wind }\left(\mathbf{k m ~ h}^{-1}\right)\end{array}$ & $\begin{array}{c}\text { Direction of } \\
\text { the wind }\left({ }^{\mathbf{N} V}\right)\end{array}$ \\
\hline & 1 & $14 / 08 / 06$ & 16 & 60 \\
& 2 & $15 / 08 / 06$ & 14 & 50 \\
Without & 3 & $16 / 08 / 06$ & 16 & 40 \\
lettuce cover & 4 & $17 / 08 / 06$ & 9 & 200 \\
crop & 5 & $18 / 08 / 06$ & 17 & 132 \\
& 6 & $19 / 08 / 06$ & 11 & 219 \\
& 7 & $20 / 08 / 06$ & 13 & 212 \\
& 8 & $21 / 08 / 06$ & 14 & 200 \\
& 9 & $22 / 08 / 06$ & 16 & 100 \\
& 10 & $23 / 08 / 06$ & 11 & 100 \\
\hline With & 1 & $18 / 10 / 06$ & 21 & 120 \\
lettuce & 2 & $19 / 10 / 06$ & 17 & 110 \\
cover crop & 3 & $20 / 10 / 06$ & 16 & 122 \\
& 4 & $21 / 10 / 06$ & 20 & 90 \\
& 5 & $22 / 10 / 06$ & 15 & 110 \\
& 7 & $23 / 10 / 06$ & 18 & 100 \\
& 8 & $24 / 10 / 06$ & 22 & 120 \\
& 9 & $25 / 10 / 06$ & 13 & 60 \\
& 10 & $27 / 10 / 06$ & 14 & 50 \\
& & & 9 & 40 \\
\hline
\end{tabular}

coefficient (Equation 3); Christiansen uniformity coefficient (Equation 4); Hawaiian uniformity coefficient (Equation 5) and statistical uniformity coefficient (Equation 6) according to the

\section{Equations}

$$
\begin{aligned}
& \mathrm{ym}=\left(\frac{\sum_{\mathrm{i}=1}^{\mathrm{n}} \mathrm{Xi}}{\mathrm{n}}\right) \\
& \mathrm{Ia}=\left(\frac{\mathrm{Q}}{\mathrm{S}}\right) \\
& \mathrm{UDC}=\frac{\mathrm{y}_{25}}{\mathrm{ym}} \cdot 100
\end{aligned}
$$

$C U C=100 \cdot\left(\frac{\sum_{i=1}^{n}|x i-y m|}{n \cdot y m}\right)$

$\mathrm{HUC}=\left(1-\sqrt{\frac{2}{\pi} \cdot \frac{\mathrm{s}}{\mathrm{ym}}}\right) \cdot 100$

$\mathrm{SUC}=\left(1-\frac{\mathrm{s}}{\mathrm{ym}}\right) \cdot 100$ its respective evaluation parameters and with the graphic distribution of the irrigation depth.

The results were analyzed statistically with the Sisvar program by using the test of Tukey at $5 \%$ of significance to determine the best performances in each treatment.

\section{RESULTS AND DISCUSSION}

With the collected data we designed the graphic distribution of the water depths average without cover crop for the individual sprinkler (Figure 1). The values of the the sprinkler's individual test and of the space simulation were then calculated (Table 2). The average water depths expected under the test conditions were $1.0 \mathrm{~mm}$ for the individual sprinkler and $5.6 \mathrm{~mm}, 3.7 \mathrm{~mm}$ and $2.5 \mathrm{~mm}$ for the spaces $12 \times 12 \mathrm{~m}, 12 \times 18 \mathrm{~m}$ and $18 \mathrm{x}$ $18 \mathrm{~m}$, respectively.

The high wind speed during the experiment did not permit to reach the expected water depths (Table 1), from $9 \mathrm{~km} \mathrm{~h}^{-1}\left(2.50 \mathrm{~m} \mathrm{~s}^{-1}\right)$ to $17 \mathrm{~km} \mathrm{~h}^{-1}(4.72$ $\mathrm{m} \mathrm{s}^{-1}$ ) for the treatment without cover crop and from $9 \mathrm{~km} \mathrm{~h}^{-1}\left(2.50 \mathrm{~m} \mathrm{~s}^{-1}\right)$ to $22 \mathrm{~km} \mathrm{~h}^{-1}\left(6.22 \mathrm{~m} \mathrm{~s}^{-1}\right)$ with treatment with cover crop. This is a typical climatic characteristic in the region of Presidente Prudente, with strong and dry winds which increase losses by drift and evaporation during the irrigation period.

The cover crop interfered and reduced the evaluation parameters for individual sprinklers (Table 2). According to Alves et al. (2001) the interception of water through the cover crop has been studied by different authors, mainly regarding forestal ecosystems and large field perennial cultures. However, there are few studies on annual cultures published.

The water depth average observed with the presence of cover crop represented $44 \%$ of the water depth average without cover crop. The treatment without cover crop presented a water depth average (ym) statistically equal to the expected water depth whereas the treatment with cover crop did not present the expected water depth of $1.0 \mathrm{~mm}$ (Figure 2A). Such fact leads 
Table 2. Sprinkler AGROPOLO NY-30 evaluation parameters, for the treatment without cover crop (1) and with cover crop (2) (parâmetros de avaliação do aspersor AGROPOLO NY-30, para o tratamento sem cobertura vegetal (1) e o tratamento com cobertura vegetal (2)). Presidente Prudente, UNOESTE, 2006.

\begin{tabular}{lccccccc}
\hline \multirow{2}{*}{ Treatment } & & Ym (mm) & $\begin{array}{c}\text { Ia } \\
\left(\mathbf{m m ~ h}^{-1}\right)\end{array}$ & UDC (\%) & CUC (\%) & HUC (\%) & SUC (\%) \\
\hline \multirow{3}{*}{ Individual sprinkler } & 1 & $0.9 \mathrm{a}$ & $3.7 \mathrm{a}$ & $28 \mathrm{a}$ & $59 \mathrm{a}$ & $57 \mathrm{a}$ & $46 \mathrm{a}$ \\
& 2 & $0.4 \mathrm{~b}$ & $1.6 \mathrm{~b}$ & $15 \mathrm{~b}$ & $40 \mathrm{~b}$ & $45 \mathrm{~b}$ & $31 \mathrm{~b}$ \\
& $\mathrm{CV}(\%)$ & 17.0 & 17.0 & 28.1 & 14.7 & 11.93 & 20.0 \\
\hline \multirow{3}{*}{$12 \times 12 \mathrm{~m}$} & 1 & $4.2 \mathrm{a}$ & $16.6 \mathrm{a}$ & $79 \mathrm{a}$ & $87 \mathrm{a}$ & $86 \mathrm{a}$ & $82 \mathrm{a}$ \\
& 2 & $1.8 \mathrm{~b}$ & $7.2 \mathrm{~b}$ & $78 \mathrm{a}$ & $87 \mathrm{a}$ & $83 \mathrm{a}$ & $79 \mathrm{a}$ \\
& $\mathrm{CV}(\%)$ & 18.0 & 18.0 & 10.1 & 5.69 & 6.1 & 7.9 \\
\hline \multirow{3}{*}{$12 \times 18 \mathrm{~m}$} & 1 & $2.8 \mathrm{a}$ & $11.1 \mathrm{a}$ & $73 \mathrm{a}$ & $81 \mathrm{a}$ & $81 \mathrm{a}$ & $76 \mathrm{a}$ \\
& 2 & $1.2 \mathrm{~b}$ & $4.8 \mathrm{~b}$ & $68 \mathrm{a}$ & $77 \mathrm{a}$ & $77 \mathrm{a}$ & $71 \mathrm{a}$ \\
& $\mathrm{CV}(\%)$ & 18.0 & 18.1 & 13.7 & 10.4 & 8.7 & 11.8 \\
\hline \multirow{3}{*}{$18 \times 18 \mathrm{~m}$} & 1 & $1.9 \mathrm{a}$ & $7.4 \mathrm{a}$ & $66 \mathrm{a}$ & $76 \mathrm{a}$ & $75 \mathrm{a}$ & $69 \mathrm{a}$ \\
& 2 & $0.8 \mathrm{~b}$ & $3.2 \mathrm{~b}$ & $62 \mathrm{a}$ & $74 \mathrm{a}$ & $73 \mathrm{a}$ & $66 \mathrm{a}$ \\
& $\mathrm{CV}(\%)$ & 18.0 & 18.0 & 15.1 & 11.2 & 10.0 & 13.6 \\
\hline
\end{tabular}

Means followed by the same letter in the column did not differ from each other, Tukey test, $\mathrm{p}<0.05$ (médias seguidas de mesma letra nas colunas não diferem significativamente entre si, teste de Tukey, $\mathrm{p}<0,05)$. $\mathrm{Ym}=$ average size depth applied; Ia $=$ instantaneous application rate; $\mathrm{UDC}=$ uniformity of distribution coefficient $\mathrm{CUC}=$ Christiansen uniformity coefficient; HUC $=$ Hawaiian uniformity coefficient and $\mathrm{SUC}=$ statistical uniformity coefficient $(\mathrm{Ym}=$ lâmina média aplicada; Ia= intensidade de aplicação, UDC= coeficiente de uniformidade de distribuição; $\mathrm{CUC}=$ coeficiente de uniformidade de Christiansen; $\mathrm{CUH}=$ coeficiente de uniformidade havaiano e $\mathrm{CUE}=$ coeficiente de uniformidade estatístico).

to a hydric deficiency in the culture, considering that the main objective of the irrigation is to apply the necessary water depth to the radicular zone of the plant for its full development, according to Kara et al. (2008).
Regarding the instantaneous application parameter, the treatment with cover crop represented $43 \%$ of the value observed in the treatment without cover crop. For the other parameters, the interference in the treatment with cover

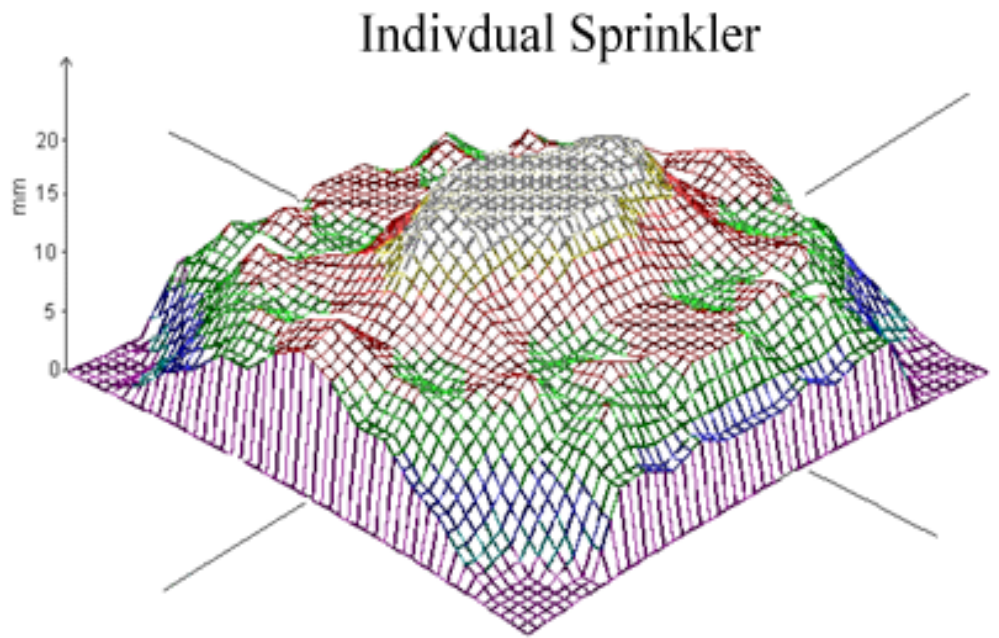

Spacing between collectors $1.5 \mathrm{~m}$

Sprinkler located in the center

Figure 1. Depth distribution for individual sprinkler AGROPOLO NY-30 without cover crop (distribuição das lâminas para o aspersor AGROPOLO NY-30 individual sem cobertura vegetal). Presidente Prudente, UNOESTE, 2006.

crop was smaller in spite of presenting the same tendency, whose values were $54 \%$ of CUD, $68 \%$ of CUC, $79 \%$ of $\mathrm{HUC}$ and $67 \%$ of SUC in relation to the treatment without the cover crop (Table 2).

The cover crop interfered with the water distribution in the area due to the fact that the height of the water applied from the sprinkler was above the height of the adult plant thus preventing its penetration in the soil, as the water was retained by the leaves.

In the simulations with overlapping, only the water depth and the application rate showed significant differences. The values obtained in the treatment with cover crop led to $43 \%$ of the water depth, except for the spacing of $18 \times 18$ $\mathrm{m}$, which had $50 \%$ of the water depth applied compared to the treatment without cover crop. The treatment with cover crop promoted $43 \%$ of the instantaneous application rate in all the simulations compared to the treatment without cover crop (Table 2). There was no significant difference for the other parameters, which indicates that the right overlapping eliminated the lack of uniformity in the irrigation promoted by the cover crop. 

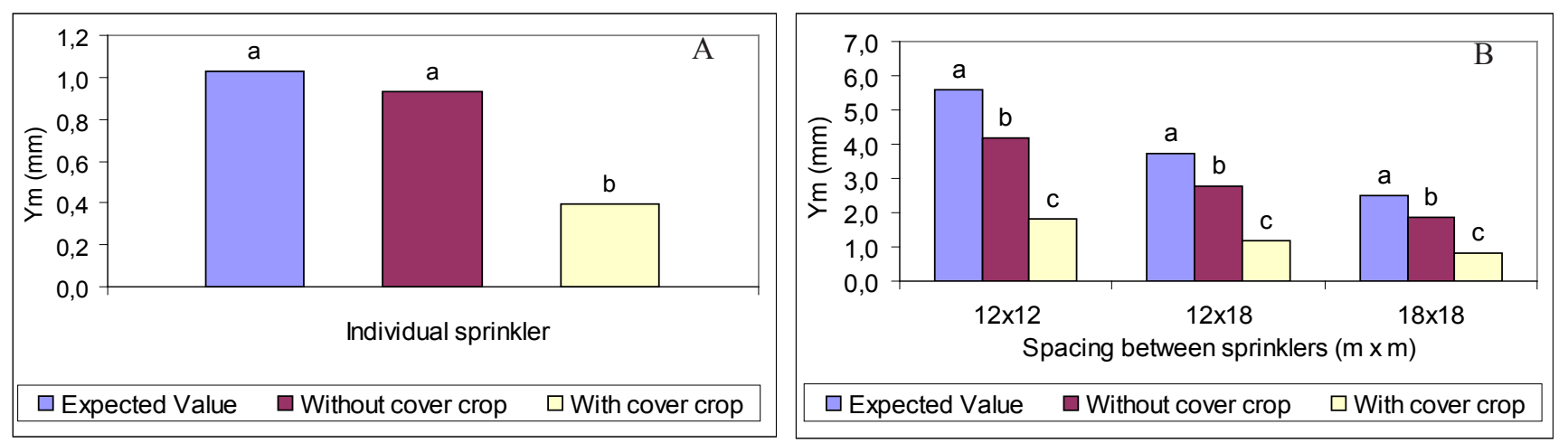

Figure 2. Average water depth observed in the test for the sprinkler AGROPOLO NY-30. A) Individual sprinkler and spacing B) $12 \mathrm{x} 12$ m, 12 x 18 m e 18 x 18 m (lâminas médias observadas no ensaio para o aspersor AGROPOLO NY-30. A) Aspersor individual e B) espaçamentos 12 x 12 m, 12 x 18 m e 18 x 18 m). Presidente Prudente, UNOESTE, 2006.

After evaluating the sprinkler irrigation uniformity and efficiency in different spacing dispositions using CATCH-3D, Kara et al. (2008) realized that the increase in spacings causes a fall in the uniformity coefficient. Therefore, they consider the tests in field and simulations as important tools to select the adequate spacing and assure acceptable uniformity values. Regarding the situation tested, the uniformity values were only acceptable for the spacing 12 × $12 \mathrm{~m}$ : UDC between $70 \%$ and $80 \%$ and CUC between $82 \%$ and 88\% (Frizzone \& Botrel, 1996; Zocoller, 1999; Paz et al., 2002; Kara et al., 2008). In the other spacing $(12 \times 18 \mathrm{~m}$ e $18 \mathrm{x}$

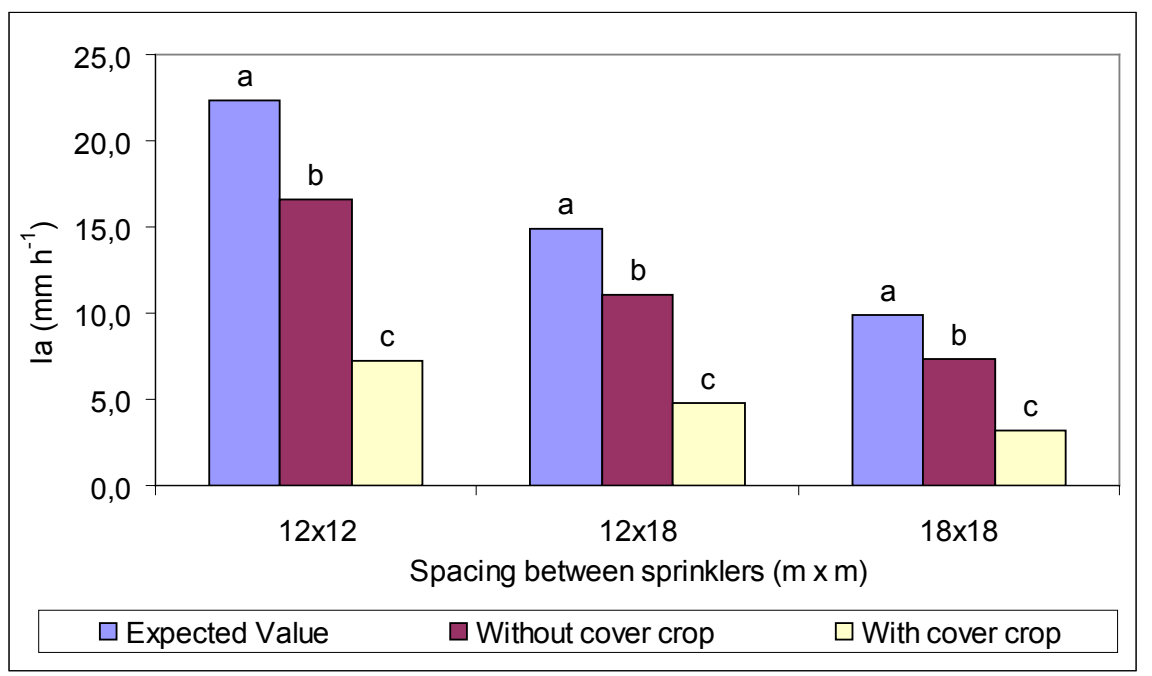

Figure 3. Instantaneous application rate observed in the sprinkler's test. AGROPOLO NY30 for spacing $12 \times 12$ m, $12 \times 18$ m e $18 \times 18$ m (intensidades de aplicação observadas no ensaio para o aspersor AGROPOLO NY-30 nos espaçamentos 12 x 12 m, 12 x 18 m e 18 x $18 \mathrm{~m})$. Presidente Prudente, UNOESTE, 2006.

$18 \mathrm{~m}$ ) occurred a lack of uniformity in the irrigation (Table 2).

When analyzing the average water depth in the spacing (Figure 2B) and the instantaneous application rate in the spacing (Figure 3), neither treatment reached the expected value. The treatment with cover crop presented the lower value for both parameters with a water depth below the expected. At the end of the cycle, the cover crop retained $2.4 \mathrm{~mm} ; 1.6 \mathrm{~mm}$ and $1.1 \mathrm{~mm}$ of the water depth applied when the sprinklers were in spacing of $12 \times 12 \mathrm{~m} ; 12 \times 18 \mathrm{~m}$ and $18 \times 18 \mathrm{~m}$, respectively.

Therefore, we can conclude that the cover crop reduced the uniformity 
p. $546-547$.

ANDRADE JÚNIOR AS; DUARTE RLR; RIBEIRO VQ. 1992. Resposta de cultivares de alface a diferentes níveis de irrigação. Horticultura Brasileira 10: 95-97.

BERNARDO S; SOARES AA; MANTOVANI EC. 2005. Manual de Irrigação, 7.ed. Viçosa: UFV. 611p.

BRENNAN D. 2007. Policy interventions to promote the adoption of water saving sprinkler systems: the case of lettuce on the Gnangara Mound. Australian Journal of Agricultural and Resource Economics 51: 323-341.

BRENNAN D. 2008. Factors affecting the economic benefits of sprinkler uniformity and their implications for irrigation water use. Irrigation Science 26: 109-119.

CHRISTIANSEN EJ. 1942. Irrigation by sprinkling. Berkeley: University of California Experiment Station. 124p. (Bulletin 670)

DRUMOND LCD; ZANINI JR; FERNANDES ALT; RODRIGUES GP. 2006. Uniformidade de distribuição superficial e subsuperficial de água e de água residuária de suinocultura com irrigação por aspersão em malha. Engenharia Agrícola 26: 415-425.

FREITAS PSL; REZENDE R; MANTOVANI EC; FRIZZONE JA. 2003. Viabilidade de inserção dos efeitos da uniformidade de irrigação em modelos de crescimento de culturas. Revista Brasileira de Engenharia Agrícola e Ambiental 7: 437-444.

FRIZZONE JA. 1992. Irrigação por aspersão: uniformidade e eficiência. Piracicaba: ESALQDepto. Engenharia Rural. 53p. (Série Didática, 003).
FRIZZONE JA; BOTREL TA. 1996. Ensaio \& certificação de sistemas para irrigação. In: MIALHE LG. Máquinas Agrícolas - Ensaios e Certificações. Piracicaba: FEALQ. p. 571634.

FRIZZONE JA; DOURADO NETO D. 2003. Avaliação de sistemas de irrigação. In: MIRANDA JH; PIRES RCM. Irrigação. Piracicaba: FUNEP, p.573-652.

HART WE. 1961. Overhead irrigation pattern parameters. Agricultural Engineering 42: 345-355.

KARA T; EKMEKCI E; APAM M. 2008. Determining the uniformity coefficient and water distribution characteristics of some sprinklers. Pakistan Journal of Biological Science 11: 214-219.

MATEOS L. 2006. A simulation study of comparison of the evaluation procedures for three irrigation methods. Irrigation Science 25: $75-83$.

PAZ VPS; FRIZZONE JA; BOTREL TA; FOLEGATTI MV. 2002. Otimização do uso da água em sistemas de irrigação por aspersão. Revista Brasileira de Engenharia Agrícola e Ambiental, 6: 404-408.

PEREIRA GM. 2003. Aspersão Convencional. In: MIRANDA JH; PIRES RCM. Irrigação. v.2. Piracicaba: FUNEP. p. 107-178.

REZENDE R.; FRIZZONE JA; GONÇALVES ACA; FREITAS PSL. 1998. Influência do espaçamento entre aspersores na uniformidade de distribuição de água acima e abaixo da superfície do solo. Revista Brasileira de Engenharia Agrícola e Ambiental, 2: 257261.
RODRIGUES TRI; BATISTA HS; CARVALHO JM; GONÇALVES AO; MATSURA EE. 2001. Uniformidade de distribuição de água em pivô central, com a utilização da técnica TDR na superfície e no interior do solo. Revista Brasileira de Engenharia Agrícola e Ambiental 5: 187-191.

SILVA EM; LIMA EFW; RODRIGUES LN; AZEVEDO JA. 2006. Comparação de modelos matemáticos não-lineares empregados na análise de desempenho de sistemas de irrigação. Pesquisa Agropecuária Brasileira 41: 1049-1052.

SILVA LL. 2006. The effect of spray head sprinklers with different deflector plates on irrigation uniformity, runoff and sediment yield in a Mediterranean soil. Agricultural Water Management 85: 243-252.

SILVA VF; BEZERRA NETO F; NEGREIROS MZ; PEDROSA JF. 2000. Comportamento de cultivares de alface em diferentes espaçamentos sob temperatura e luminosidade elevadas. Horticultura Brasileira 18: 183-187.

TRANI PE; TIVELLI SW; PURQUERIO LFV; AZEVEDO FILHO JA. 2005. Hortaliças, alface (Lactuca sativa L.). Disponível em: http://www.iac.sp.gov.br/Tecnologias/Alface/ Alface.htm. Acessado em 20 de novembro de 2006.

WILCOX JC; SWAILES GE. 1947. Uniformity of water distribution by some undertree orchard sprinklers. Scientific Agriculture 27: 565-583.

ZOCOLLER, JL. 1999. Avaliação do desempenho de sistemas de irrigação. Disponível em http:// www.agr.feis.unesp.br/curso5.htm Acessado em 07 de abril de 2009. 